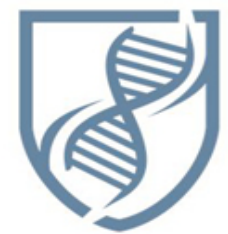

Journal of Bioscience and Applied Research

\section{JBAAR}

WWW.JBAAR.ORG

\title{
The role of Caselio (plant fertilizer) exposure on digestive gland histology and heavy metals accumulation in the freshwater snail, Lanistes carinatus
}

\author{
Sherin K. Sheir \\ Department of Zoology, Menoufia University, Shebeen El-koom, Egypt. \\ *Corresponding author: E-mail: sherin.sheir@yahoo.com
}

\begin{abstract}
The adverse effects of Caselio, the plant fertilizer (PMR) on the freshwater snail, Lanistes carinatus were studied. Snails were collected from Bahr Shebeen canal, Menoufia Province, Egypt. Snails were exposed to 200 and $600 \mu 1 / 1$ of the fertilizer (PMR) for $0,1,3$ and 7 days. Shell, operculum, foot and soft tissue metals concentrations $(\mathrm{Cd}$, $\mathrm{Pb}, \mathrm{Al}, \mathrm{Cu}, \mathrm{Mg}, \mathrm{Ti}$ and $\mathrm{Na}$ ), lipid peroxidase and histopatholgy of digestive gland were investigated. Tested metals concentrations accumulated differently in the shell, operculum, foot and soft tissue under the effect of the fertilizer where soft tissue accumulated essential metals and most of the non-essential metals. Exposure to PMR caused significant increase in lipid peroxidase of snails digestive gland ranging from 52-82 \% increase than control snails $(P \leq 0.03)$. The fertilizer caused tissue damage in the digestive tubules as necrosis, fusion and increased lipofuscin pigment significantly of exposed snails` (200 and $600 \mu \mathrm{l} / \mathrm{l})$ when compared to the control group (134.33 $\pm 2.85,80.0 \pm 8.18$ and $69.33 \pm 3.18$, respectively, $P=$ 0.0003 ) after 7 days of exposure. In conclusion, different organs accumulated different amounts of essential and nonessential metals under the effect of PMR. The fertilizer caused lipid peroxidation and lipofuscin pigments increase (aging) to the digestive gland of $L$. carinatus.
\end{abstract}

Keywords: Fertilizer, Lanistes carinatus, Metals, Lipid peroxidase, Digestive gland.

\section{Introduction}

For biomonitoring the aquatic systems, there are many criteria for choosing an organism. The organism should be relatively sedentary, widespread and have a moderate life span, accumulate metals from food, water to meet the criteria as good bioindicators (Huang et al. 2007). Metal accumulation in the environment can be a result of both natural and anthropogenic sources. Different Metal concentrations in aquatic ecosystems affect vertebrates and invertebrates of the environment, by modulating their biological activities in several pathways (Rockwood et al., 1990; Kar et al., 2015). Accumulation of metals depends on many parameters. Ibrahim and Mat (1995) showed that the total metal $(\mathrm{Mg}, \mathrm{Cl}, \mathrm{Mn}, \mathrm{K}, \mathrm{Se}, \mathrm{Br}, \mathrm{Zn}, \mathrm{Co}, \mathrm{Fe}, \mathrm{Rb}$ and $\mathrm{Cd})$ content is directly proportional to the body weight. Dodd (1965) recorded a relationship between shell size in Mytilus sp. and magnesium concentration in the prismatic layer of the shell.

Plant fertilizers are good for plants and increase vegetative production as it supply the plant with nutrients. There are many types of fertilizers; single, binary and multinutrients. Nitrogen fertilizers are made of ammonia $\left(\mathrm{NH}_{3}\right)$. Compound fertilizers contain $\mathrm{N}$ and $\mathrm{P}$. liquid fertilizer has more rapid effect and easier coverage and added to the irrigation water. Agricultural run-off, where fertilizers are present is the main cause of eutrophication and consume oxygen (Werner, 2009). Nitrogen fertilizers cause soil acidification and in turn inhibit microbial activity and affect soil invertebrates. A negative relationship was found between high rates of fertilizer and populations of earth worms and beneficial invertebrates (Leslie,1994). Agriculture products will make global environmental changes (Tilman et al., 2001).

Magnesium $(\mathrm{Mg})$ is important essential metal in the basic nucleic acid chemistry of cells. Over 300 enzymes require magnesium ions for their catalytic action, such as enzymes utilizing or synthesizing ATP, or those that use other nucleotides to synthesize DNA and RNA. Loss of $\mathrm{Mg}^{2+}$ of some tissues caused defective transport, hormonal stimulation, or metabolic impairment (Romani, 2013). Copper $(\mathrm{Cu})$ is an essential element; however its deficiency/toxicity could cause health problems of the organisms. It is essential in metabolic functions as it is a part of proteins, enzymes, bone and connective tissue (Osredkar and Sustar, 2011) and haemolymph of molluscs (Rainbow and White, 1985). Exposure to heavy metals such as $\mathrm{Cu} \mathrm{SO}_{4}$, can cause disturbance in osmoregulation 
of the animals tissues (Hu et al., 2015). Secretion of mucous is a sign of $\mathrm{Cu}$ toxicity as recorded by Gupta et al., (1981).

Aluminium $(\mathrm{Al})$ is non-essential metal for biological systems. The amount of $\mathrm{Al}$ in solution coming from the normal weathering is a small part of the total $\mathrm{Al}$ in the environment from other sources. However, surface water contains a large part of $\mathrm{Al}$. Inorganic $\mathrm{Al}$ increase with acidic water and organic $\mathrm{Al}$ increase with increase of dissolved organic matters. Al bioavailability increases with increase of acidity (under $\mathrm{pH}$ 5.0) and decrease of temperature and coupled with drainage lakes (Driscoll and Postek, 1996). Al toxicity could be increased by coupling with phosphorous as $\mathrm{AlPO}_{4}$ (Driscoll and Postek, 1996) or could be reduced with addition to Ca (Daphnia magna, Havas, 1985). In addition, $\mathrm{Al}$ at low $\mathrm{pH}$ affected respiration of the dragonfly Libellula julia Uhler (Rockwood et al, 1990). Cadmium (Cd) uptake depended on the external metal concentration (the shore crab, Carcinus maenas, Martin and Rainbow, 1998). Rainbow and Black (2005) studied the effects of salinity and osmolality differences on the uptake rates of dissolved cadmium in 3 crabs of different ecologies. Lead $(\mathrm{Pb})$ is a highly poisonous metal affecting almost every organ and system in the body. Long exposure to dietary $\mathrm{Pb}$ caused growth deficiency in the snail, Theba pisana (El-Gendy et al., 2011). Titanium (Ti) is a biocompatible metals (it is non-toxic and is not rejected by the body). Ti introduced in many medical uses, like surgical implants (joint replacement) and it is not harmful nor plays any biological role in the human body (Emsley, 2001). Pyatt et al., (1997) recorded Ti in the tissues of the freshwater snails, Lymnaea stagnalis and not detected in water samples collected from unpolluted site.

$\mathrm{Cd}, \mathrm{Cu}$ and $\mathrm{Pb}$ were analysed in different part of the gastropod Nerita lineata collected from different sites in the west intertidal area of Peninsular Malaysia, in soft tissues, shell and operculum (Yap and Cheng, 2009). Cd, $\mathrm{Co}, \mathrm{Cu}, \mathrm{Fe}, \mathrm{Mg}, \mathrm{Mn}, \mathrm{Pb}$ and $\mathrm{Zn}$ were anaylzed in the sediment, shell and tissue of different molluscs at south coast of India. The authors found tissue specific accumulation of the investigated metals (Kesavan et al., 2013).

Biomarkers are defined as a biological response to chemical(s) that give a measure of exposure or effect (Peakall, 1994). Lipid peroxidation refers to the oxidative degradation of lipids where free radicals take electrons from the lipids in cell membranes, resulting in cell damage. One of the end products of lipid peroxidation are reactive aldehydes, such as malondialdehyde (MDA, Buege and Aust, 1978). Siwela et al. (2010) studied the effect of polluted water and sediments on the freshwater snails, Lymnaea natalensis lipid peroxidase. They recorded significant increase in levels of MDA in the snails tissues exposed to polluted water and sediments. Heavy metals ( $\mathrm{Zn}, \mathrm{Cu}, \mathrm{As}, \mathrm{Cd}, \mathrm{Pb}$ and $\mathrm{Hg}$ ) were analyzed in the bivalve molluscs, mussels, clams, oysters from different sites in China and compared to each other for biomonitoring purposes (Huang et al. 2007).
Histopathological studies showed variety of organs damage in molluscs exposed to anthropogenic agents. The contamination may be direct by water or indirect by food. Clearly, food route exposure is a concern, because it could be circulated with body circulation. Histological alterations of the liver and vital organs were recorded in the animals reared near the industrial areas (Kar et al., 2015). Exposure to $\mathrm{Cd}$ caused morphological and histological malformations of the siphones and gills of the marine clam Venerupisa urea (Mohamadein and Desouky, 2002). Many researchers investigated digestive gland as target organ for pollution (the freshwater snail, Lymnaea stagnalis; Lance et al., 2010, the Land Snail Helicella vestalis; Sharaf et al., 2015).

The objectives of this study were to evaluate the role of Caselio, the plant fertilizer on the digestive gland and metal accumulation in the adult freshwater snail, Lanistes carinatus by examining digestive gland histology and lipid peroxidase activity and detecting the pattern of metals accumulation in different tissues.

\section{Materials and methods}

\subsection{Animals}

The freshwater snails, L. carinatus were collected from Bahr Shebeen Canal at Winter (2014), (body weight, $6.47 \pm$ $0.21 \mathrm{gm})$ and transported in field water to the laboratory. Snails were held after collection for three weeks for acclimation in filtered declorinated tap water in tanks $(5 \mathrm{~L}$ tanks, length: 25 , width: 16 , height: $15.5 \mathrm{~cm}$ ) filled with 1 litre/tank. The snails were maintained under laboratory conditions with photoperiod $12 \mathrm{~h}$ light: $12 \mathrm{~h}$ dark and water $\mathrm{pH}$ was $7.3 \pm 0.2$.

\subsection{Experimental material}

Caselio (fertilizer) is a plant metabolism regulator (PMR) in solution form [contains $7 \% \mathrm{~N}, 20 \% \mathrm{P}_{2} \mathrm{O}_{3}, 4 \% \mathrm{Zn}, 1.8 \%$ $\mathrm{Fe}, 1.3 \% \mathrm{Mn}$ and $4.5 \%$ free amino acids (w/v)]. Caselio is a product of international Egypt Chem, under registry licence No. 2593.

\subsection{Experimental design}

After 2-weeks of acclimatization to the laboratory conditions, adult $L$. carinatus snails were divided into three groups (one control and two concentrations of the fertilizer [PMR]). Each group consisted of three replicates (10 individual/replicate). The chosen sublethal concentrations was determined according to Sheir, (2015). The $1^{\text {st }}$ group (control) was kept in filtered declorinated tap water, the $2^{\text {nd }}$ group treated with the fertilizer, PMR $\left(200 \mu \mathrm{l} / 1, \mathrm{LC}_{10}\right)$, and the $3^{\text {rd }}$ group treated with the fertilizer, PMR $(600 \mu \mathrm{l} / 1$, $\mathrm{LC}_{30}$ ). Tanks water were re-dosed every other day after a $100 \%$ water change, and snails were fed on fresh green lettuces. Snails were sampled on day $0,1,3$, and 7. The assessed parameters were metals analysis $(\mathrm{Cu}, \mathrm{Al}, \mathrm{Mg}$ and Ti) in shell, $(\mathrm{Cu}, \mathrm{Al}, \mathrm{Pb}$ and $\mathrm{Cd})$ in operculum, $(\mathrm{Cu}, \mathrm{Al}, \mathrm{Cd}$, $\mathrm{Pb}$ and $\mathrm{Na}$ ) in foot, and soft tissue, and lipid peroxidase and histology in digestive gland. 


\subsection{Metal analysis in tissue}

Tissue samples were prepared according to Federici et al. (2007) with minor modifications. Briefly, about $0.05 \mathrm{~g}$ of fresh tissue (shell, operculum, foot and soft tissue) was oven dried, digested in $1 \mathrm{ml}$ of concentrated $\mathrm{HNO}_{3}$ at $70{ }^{\circ} \mathrm{C}$, and then diluted to a final volume of $5 \mathrm{ml}$ with distilled water. Total $\mathrm{Cd}, \mathrm{Pb}, \mathrm{Al}, \mathrm{Mg}, \mathrm{Ti}$ and $\mathrm{Cu}$ were measured using Inductively Coupled Argon Plasma, iCAP 6500 Duo (Thermo Scientific, England) against $1000 \mathrm{mg} / \mathrm{l}$ multielement certified standard solution (Merck, Germany) as stock solution for instrument standardization. $\mathrm{Na}$ was measured by Flame Photometer, PFP 7, Jenway, UK.

\subsection{Lipid peroxidase}

Lipid peroxidase (LPO) forms malondialdehyde (MDA) as one of the products of oxidative stress. The concentrations of malondialdehyde (MDA) as a marker of LPO were determined according to Nair and Turner (1984) based on the reaction with thiobarbituric acid (TBA) with minor modifications. Briefly, $10 \mathrm{mg}$ of digestive gland homogenate was mixed with $300 \mu \mathrm{l}$ of MDA lysing buffer, and then centrifuged at $13,000 \mathrm{~g}$ for $10 \mathrm{~min}$. MDA level was measured colorimetrically at $532 \mathrm{~nm}$ against MDA standard curve. MDA were expressed as $\mathrm{nM} / \mathrm{mg}$ of MDA of wet tissue.

\subsection{Histology of digestive gland}

For histological examination, three snails were selected randomly from each experimental groups including the control group. The most proximal part of the digestive gland was collected after 7 days of the experiment. Digestive gland was dissected and immediately fixed in Bouin`s fluid. After fixation for $24 \mathrm{~h}$, specimens were dehydrated in an ascending series of alcohol. The specimens were cleared in xylene and embedded in melted paraplast at $60{ }^{\circ} \mathrm{C}$. Serial sections were cut at $6 \mu \mathrm{m}$ thickness and stained with Ehrlich`s Haematoxylin and counterstained by Eosin (Romeis, 1989). The sections were then mounted and covered with glass cover. Histological sections were photographed using Olympus b x. 41, Japans microscope, photo-automated camera. The number of tubules, total number of lipofuscin pigment and number of lipofuscin pigment/tubule were measured on collected images $(20 \mathrm{X})$, and a mean for each section was derived by randomly counting three replicates from a randomly selected area on a section from each snail (Weibel et al. 1966).

\subsection{Statistical analysis}

All data were analysed using Statgraphics (v5.1 software). Data were expressed as mean $\pm \mathrm{SE}$. Statistical analysis was carried by One-way ANOVA to set the difference between the control and treated groups, setting the probability level to $P \leq 0.05$, where ANOVA could not be applied, Kruskal Wallis test was used.

\section{Results}

3.1. Effect of the fertilizer (PMR) on some metals accumulation in Lanistes carinatus tissues
Metals chosen for representation in the results were different from one organ to another because it depended on its accumulation capacity and others were under detection limits of the chemical analysis.

\subsubsection{The shell}

$\mathrm{Cu}, \mathrm{Al}, \mathrm{Mg}$ and $\mathrm{Ti}$ accumulation were analysed in the shell of the snails by day 7. The fertilizer, PMR exposure caused large increases $(1.4,1.3$ and 1.1 fold) in $\mathrm{Cu}$ concentration of the shell in the exposed snails to $200 \mu \mathrm{l} / 1$ for 1,3 and 7 days, respectively (ANOVA, $P>0.05$ ). However, $600 \mu \mathrm{l} / 1$ caused decrease in the content of $\mathrm{Cu}$ in the exposed snails than the control (Table 1). Al concentration followed the same pattern as $\mathrm{Cu}$ in accumulation. $200 \mu \mathrm{l} / 1$ exposed snails shell accumulated $\mathrm{Al}$ more than the control and 600 $\mu 1 / 1$ snails. Meanwhile, $600 \mu 1 / 1$ exposed snails lost its content of Al more than control and $200 \mu \mathrm{l} / \mathrm{l}$ snails significantly (ANOVA, $P \leq 0.03$ ) on $3^{\text {rd }}$ and $7^{\text {th }}$ days. $\mathrm{Mg}$ increased in $200 \mu \mathrm{l} / 1$ exposed snails than the control and $600 \mu \mathrm{l} / 1$ snails. The fertilizer, PMR exposure caused reduction in content of $\mathrm{Mg}$ of $600 \mu \mathrm{l} / \mathrm{l}$ exposed snails' shell significantly (ANOVA, $P \leq 0.04$ ) than the control and 200 $\mu \mathrm{l} / 1$ on $1^{\text {st }}$ and $3^{\text {th }}$ days. Ti content in the shell of control and exposed snails were significantly higher in accumulation at 0 and $1^{\text {st }}$ days (kruskal wallis, $P=0.03$ ), then all groups including the control decreased the $\mathrm{Ti}$ content by days 3 and 7 to be similar in concentration.

\subsubsection{The operculum}

The fertilizer, PMR exposure caused disturbance (increase/decrease) in $\mathrm{Cu}$ concentration of the operculum of exposed snails to both concentrations than the control. On the $3^{\text {rd }}$ day, PMR caused significant reduction in $\mathrm{Cu}$ content in $200 \mu \mathrm{l} / \mathrm{l}$ exposed groups than the control and 600 $\mu \mathrm{l} / 1$ groups (ANOVA, $P=0.04$, Table 2). Al concentration in the operculum of exposed snails recorded significant increase than the control group during the whole experimental period especially on the $1^{\text {st }}$ and $3^{\text {rd }}$ days (ANOVA/ Kruskal wallis, $P \leq 0.04$ ). The fertilizer, PMR $(600 \mu \mathrm{l} / \mathrm{l})$ caused significant increase in $\mathrm{Pb}$ concentration on day 1 (Kruskal wallis, $P=0.02$ ) more than the control and $200 \mu \mathrm{l} / 1$ exposed groups. Then, $\mathrm{Pb}$ content decreased than the control in the following days of the experiments $\left(7^{\text {th }}\right.$ day, ANOVA, $\left.P=0.05\right)$. Cd content generally recorded significant increase in all exposed snails operculum (ANOVA/ Kruskal wallis, $P \leq 0.05$ ) than control or between treatments.

\subsubsection{The foot}

The fertilizer, PMR exposure caused increases in $\mathrm{Cu}$ concentration of the foot in the exposed snails to both concentrations on the $1^{\text {st }}$ day. However, decreased for the rest of the experimental time especially on the $7^{\text {th }}$ day by $600 \mu 1 / 1$ treatment (ANOVA, $P=0.05$, Table 3). Al content decreased in both treatments for the total experimental time and continued its significant decrease than the control on $3^{\text {rd }}$ and $7^{\text {th }}$ days (Kruskal wallis, $P=0.02$ ). The fertilizer, PMR exposure caused significant increase in accumulation of $\mathrm{Cd}$ for both concentrations of the complete experimental period 
Tab1e 1. Total $\mathrm{Cu}, \mathrm{Al}, \mathrm{Mg}$ and Ti concentrations in the shell of L. carinatus for 7 days exposure to the fertilizer (PMR)

\begin{tabular}{cccccc} 
Time & Treatments & $\mathrm{Cu}$ & $\mathrm{Al}$ & $\mathrm{Mg}$ & $\mathrm{Ti}$ \\
\hline Zero & Control & $6.3 \pm 1.9$ & $100.22 \pm 9.60$ & $134.01 \pm 4.48$ & $54.29 \pm 6.56^{\$}$ \\
\hline \multirow{3}{*}{1 day } & Control & $6.1 \pm 1.2$ & $97.30 \pm 13.20$ & $144.02 \pm 16.41$ & $47.42 \pm 4.73^{\$}$ \\
& $200 \mu \mathrm{l} / 1$ & $8.9 \pm 2.8$ & $109.80 \pm 27.70$ & $125.02 \pm 14.62$ & $49.76 \pm 3.86$ \\
& $600 \mu \mathrm{l} / 1$ & $5.6 \pm 1.3$ & $64.30 \pm 6.70$ & $78.79 \pm 9.59^{*}$ & $51.29 \pm 6.52$ \\
\hline \multirow{3}{*}{3 days } & Control & $5.5 \pm 1.2$ & $94.69 \pm 8.17$ & $134.23 \pm 12.19$ & $11.59 \pm 0.69$ \\
& $200 \mu \mathrm{l} / 1$ & $6.9 \pm 2.3$ & $152.87 \pm 30.98$ & $130.17 \pm 10.48$ & $15.69 \pm 5.15$ \\
& $600 \mu \mathrm{l} / 1$ & $2.9 \pm 0.9$ & $24.36 \pm 1.77^{* \#}$ & $91.17 \pm 5.34^{* \#}$ & $18.01 \pm 4.97$ \\
7 days & Control & $7.8 \pm 0.9$ & $99.85 \pm 8.17$ & $146.07 \pm 14.08$ & $11.92 \pm 1.30$ \\
& $200 \mu \mathrm{l} / 1$ & $8.5 \pm 2.4$ & $110.84 \pm 7.52$ & $129.26 \pm 14.24$ & $12.22 \pm 0.71$ \\
& $600 \mu \mathrm{l} / 1$ & $6.1 \pm 1.7$ & $35.08 \pm 9.96^{* \#}$ & $125.78 \pm 2.05$ & $13.48 \pm 1.84$
\end{tabular}

Note, Data are means \pm S.E., in $\mathrm{mg} / \mathrm{g}$ dry weight $(\mathrm{dw}), n=3$ snails per group. $*$ indicates a significant difference from the control, \# indicates a significant difference between treatments and $\$$ indicates a significant difference between controls within the investigated time (Kruskal-Wallis, $P \leq 0.05$ ).

Tab1e 2. Total $\mathrm{Cu}, \mathrm{Al}, \mathrm{Pb}$ and $\mathrm{Cd}$ concentrations in the operculum of L. carinatus for 7 days exposure to the fertilizer (PMR)

\begin{tabular}{llcccc}
\hline Time & Treatments & $\mathrm{Cu}$ & $\mathrm{Al}$ & $\mathrm{Pb}$ & $\mathrm{Cd}$ \\
\hline Zero & Control & $27.5 \pm 2.5$ & $275.69 \pm 69.03$ & $4.76 \pm 1.39$ & $0.27 \pm 0.04$ \\
\hline \multirow{3}{*}{1 day } & Control & $26.2 \pm 3.4$ & $285.98 \pm 20.02$ & $4.99 \pm 1.08$ & $0.19 \pm 0.03$ \\
& $200 \mu \mathrm{l} / 1$ & $34.4 \pm 5.5$ & $399.57 \pm 50.35^{*}$ & $7.28 \pm 0.96$ & $0.94 \pm 0.12^{*}$ \\
& $600 \mu \mathrm{l} / 1$ & $27.3 \pm 0.9$ & $427.18 \pm 40.17^{*}$ & $9.64 \pm 0.19^{*}$ & $0.27 \pm 0.07 \#$ \\
\hline \multirow{3}{*}{3 days } & Control & $34.9 \pm 5.4$ & $302.76 \pm 21.59$ & $4.65 \pm 1.44$ & $0.25 \pm 0.06$ \\
& $200 \mu \mathrm{l} / 1$ & $18.4 \pm 3.6^{* \#}$ & $314.45 \pm 52.19$ & $3.63 \pm 0.18$ & $0.34 \pm 0.02$ \\
& $600 \mu \mathrm{l} / 1$ & $37.2 \pm 4.3$ & $353.59 \pm 64.89$ & $3.34 \pm 0.63$ & $0.58 \pm 0.13^{*}$ \\
\hline \multirow{3}{*}{7 days } & Control & $35.7 \pm 4.5$ & $304.32 \pm 14.76$ & $4.83 \pm 0.48$ & $0.19 \pm 0.1$ \\
& $200 \mu \mathrm{l} / 1$ & $30.5 \pm 4.4$ & $455.37 \pm 96.30^{* \#}$ & $3.48 \pm 0.27^{*}$ & $1.03 \pm 0.17^{*}$ \\
& $600 \mu \mathrm{l} / 1$ & $21.4 \pm 0.6$ & $206.12 \pm 5.97$ & $3.67 \pm 0.15^{*}$ & $1.25 \pm 0.03^{*}$
\end{tabular}

Note, Data are means \pm S.E., in $\mathrm{mg} / \mathrm{g}$ dry weight $(\mathrm{dw}), n=3$ snails per group. $*$ indicates a significant difference from the control, \# indicates a significant difference between treatments (ANOVA/Kruskal-Wallis, $P \leq 0.05$ ).

(ANOVA/ Kruskal wallis, $P \leq 0.03$ ). The increase control group and PMR caused significant reduction in its continued until reached the highest by $7^{\text {th }}$ day. The concentration in both treatments by $1^{\text {st }}$ day of the differences in percentage of the increase at 200 and 600 experiments (ANOVA, $P \leq 0.04$, Table 3). PMR caused $\mu \mathrm{l} / \mathrm{l}$ treatments than the control were as follows; $1^{\text {st }}$ day marginal changes in $\mathrm{Na}$, the electrolyte and insignificant were $47,142 \%, 3^{\text {rd }}$ day were $21,178 \%$ and $7^{\text {th }}$ day were increase/decrease in both exposed snails foot than the $172,405 \%$, respectively. $\mathrm{Pb}$ content was high in the control group during the experimental period. 
Tab1e 3. Total $\mathrm{Cu}, \mathrm{Al}, \mathrm{Cd}, \mathrm{Pb}$ and $\mathrm{Na}$ concentrations in the foot of $L$. carinatus for 7 days exposure to the fertilizer (PMR)

\begin{tabular}{|c|c|c|c|c|c|c|}
\hline Time & Treatments & $\mathrm{Cu}$ & $\mathrm{Al}$ & $\mathrm{Cd}$ & $\mathrm{Pb}$ & $\mathrm{Na}$ \\
\hline Zero & Control & $220.3 \pm 48.9$ & $36.23 \pm 9.42$ & $0.16 \pm 0.03$ & $5.08 \pm 1.09$ & $1948.8 \pm 370.0$ \\
\hline \multirow{3}{*}{1 day } & Control & $263.0 \pm 26.1$ & $38.85 \pm 9.34$ & $0.19 \pm 0.03$ & $5.83 \pm 1.41$ & $2275.0 \pm 184.3$ \\
\hline & $200 \mu \mathrm{l} / 1$ & $398.7 \pm 60.5$ & $30.04 \pm 2.21$ & $0.28 \pm 0.04$ & $6.79 \pm 1.30$ & $1978.7 \pm 185.8$ \\
\hline & $600 \mu \mathrm{l} / 1$ & $464.1 \pm 104.3$ & $31.51 \pm 2.15$ & $0.46 \pm 0.06^{* \#}$ & $1.98 \pm 0.18 *$ & $2168.6 \pm 235.0$ \\
\hline \multirow[t]{2}{*}{3 days } & $200 \mu \mathrm{l} / 1$ & $163.5 \pm 48.8$ & $26.59 \pm 2.64 *$ & $0.23 \pm 0.06$ & $0.86 \pm 0.27^{*}$ & $1819.1 \pm 182.8$ \\
\hline & $600 \mu 1 / 1$ & $189.3 \pm 20.9$ & $12.67 \pm 1.02 * \#$ & $0.53 \pm 0.06^{* \#}$ & $1.10 \pm 0.17^{*}$ & $2168.6 \pm 235.0$ \\
\hline 7 days & Control & $234.7 \pm 36.9$ & $37.67 \pm 4.92$ & $0.18 \pm 0.06$ & $5.08 \pm 1.41$ & $2169.4 \pm 120.9$ \\
\hline
\end{tabular}

Note, Data are means \pm S.E., in $\mathrm{mg} / \mathrm{g}$ dry weight $(\mathrm{dw}), n=3$ snails per group. $*$ indicates a significant difference from the control, \# indicates a significant difference between treatments (ANOVA/Kruskal-Wallis, $P \leq 0.05$ ).

\subsubsection{The soft tissue}

$\mathrm{Cu}$ concentration of the soft tissue of the exposed snails to and $2.1,5.3$ fold for the $7^{\text {th }}$ day, respectively. $\mathrm{Pb}$ both concentrations, increased at the $1^{\text {st }}$ day, and then concentration decreased after exposure to PMR than the significantly decreased than the control (ANOVA, $P \leq$ control at all time points of the experiment significantly 0.05, Table 4). Al content decreased under the effect of (ANOVA, $P=0.04$ ), except at the $1^{\text {st }}$ day, it increased by exposure to PMR at both treatments, especially at the $3^{\text {rd }} 200 \mu 1 / 1$ significantly than the control and $600 \mu 1 / 1$ (kruskal and $7^{\text {th }}$ days. Cd concentration in the exposed snails` soft wallis, $P=0.03$ ). Na of the soft tissue followed similar tissue increased significantly (ANOVA/kruskal wallis, $P \leq$ pattern of changes in concentration as in the foot. 0.03) than the control snails` at all time points of the Insignificant increase/decrease in both exposed snails` soft experiment. The increase in 200 and $600 \mu \mathrm{l} / 1$ treatments tissue when compared to the control group was recorded was $1.2,2.4$ fold for the $1^{\text {st }}$ day, 2.4, 4.6 fold for the $3^{\text {rd }}$ day during the experimental period.

Tab1e 4. Total $\mathrm{Cu}, \mathrm{Al}, \mathrm{Cd}, \mathrm{Pb}$ and $\mathrm{Na}$ concentrations in the soft tissue of L. carinatus for 7 days exposure to the fertilizer (PMR)

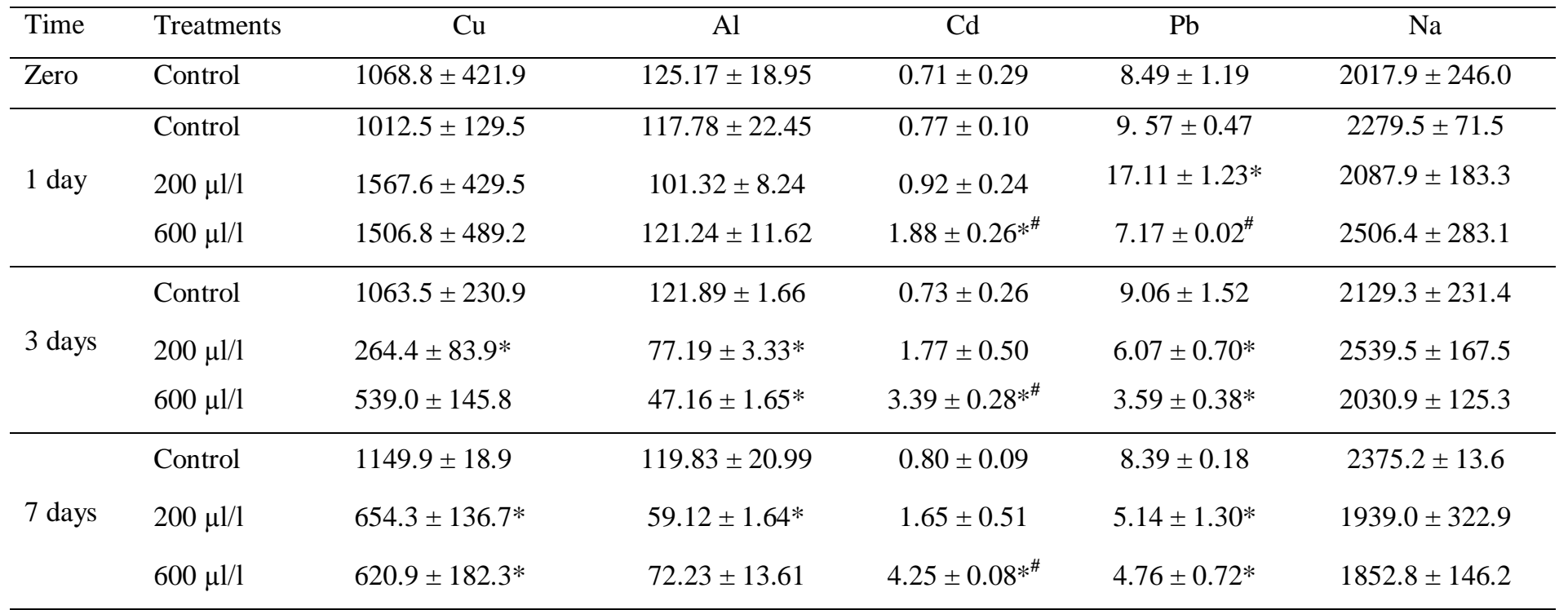

Note, Data are means \pm S.E.M., in $\mathrm{mg} / \mathrm{g}$ dry weight $(\mathrm{dw}), n=3$ snails per group. $*$ indicates a significant difference from the control, \# indicates a significant difference between treatments (ANOVA/Kruskal-Wallis, $P \leq 0.05$ ). 
Generally, the fertilizer, PMR caused increase in the accumulation of $\mathrm{Al}$ in the exposed snails' shell and operculum, but caused decrease of $\mathrm{Al}$ in foot and soft tissue. However, the treatment with the fertilizer, PMR caused disordered pattern of accumulation in $\mathrm{Cu}$ content in operculum, foot and soft tissues.

$\mathrm{Cu}$ concentration followed a pattern for accumulation magnitude in soft tissue $>$ foot $>$ operculum $>$ shell. Al content mainly accumulated in operculum $>$ soft tissue $>$ shell $>$ foot. For $\mathrm{Cd}$, soft tissue recorded the second highest accumulation after the operculum followed by the foot. $\mathrm{Pb}$ highly accumulated in the soft tissue followed by the foot then the operculum. Na content was mainly present in soft tissue followed by the foot.

\subsection{Effect of the fertilizer (PMR) on adult $L$. carinatus lipid peroxidase}

LPO levels were significantly higher in the snails exposed to PMR compared to control group (ANOVA/kruskal wallis, $P \leq 0.03$, Fig. 1). At zero time, LPO concentration in snails recorded $3.37 \pm 0.39 \mu \mathrm{M} / \mathrm{mg}$. At the $1^{\text {st }}$ day, the increase in percentages of 200 and $600 \mu \mathrm{l} / 1$ treatments than the control were $61,70 \%$, at the $3^{\text {rd }}$ day were $52,82 \%$ and at the $7^{\text {th }}$ day were $66,52 \%$, respectively.

\subsection{Histological alterations under the effect of the fertilizer (PMR) on adult $L$. carinatus digestive gland \\ The control L. carinatus digestive gland is composed of} bundles of tubules, digestive tubules. Each tubule lined by a single layer of columnar epithelial cells. The epithelial cells are divided into digestive and secretory (basophilic, calcium-excretory) cells. The two types of cells rest on basement membrane and enclose a lumen in the centre of the tubule. The tubules connected to each other by intertubular connective tissue. The average number of digestive gland tubules per image $(20 \mathrm{X})$ was $9.7 \pm 0.88$. The digestive tubules had lipofuscin pigments (69.33 \pm 3.18). The number of lipofuscin pigments/tubule was 10.89 \pm 0.68 (Figs. 2a, b and 3).

After the exposure to $200 \mu \mathrm{l} / 1$ of the plant fertilizer (PMR), some of the connective tissue became necrotic. The nuclei of epithelial cells from the digestive tubules were unclear in some cells. The most obvious symptoms of pathology were necrotic, degenerated and fused digestive tubules and cellular disintegration with almost normal connective tissue. Exposure to $600 \mu \mathrm{l} / 1$ of the plant fertilizer (PMR) caused similar pathological alterations in the digestive gland as in $200 \mu \mathrm{l} / 1$ but worse with necrotic basement membrane of some tubules. The average number of digestive gland tubules per image (20 $\mathrm{X})$ was significantly higher than $600 \mu \mathrm{l} / \mathrm{l}$ exposed snails $(13.33 \pm 1.85$ and $7.33 \pm 1.33$, respectively, kruskal wallis, $P=0.05)$. The digestive tubules had significantly higher lipofuscin pigments than $600 \mu \mathrm{l} / 1$ exposed and control snails $(134.33 \pm 2.85$ and $80.0 \pm 8.18$, respectively, ANOVA, $P=0.0003$ ). The number of lipofuscin pigments/tubule was significantly higher than $600 \mu \mathrm{l} / 1$ exposed and control snails $(16.78 \pm 1.64$ and $12.22 \pm 0.96$, respectively, ANOVA, $P=0.03$, Figs. $2 \mathrm{a}, \mathrm{b}, \mathrm{c}, \mathrm{d}$ and 3 ).

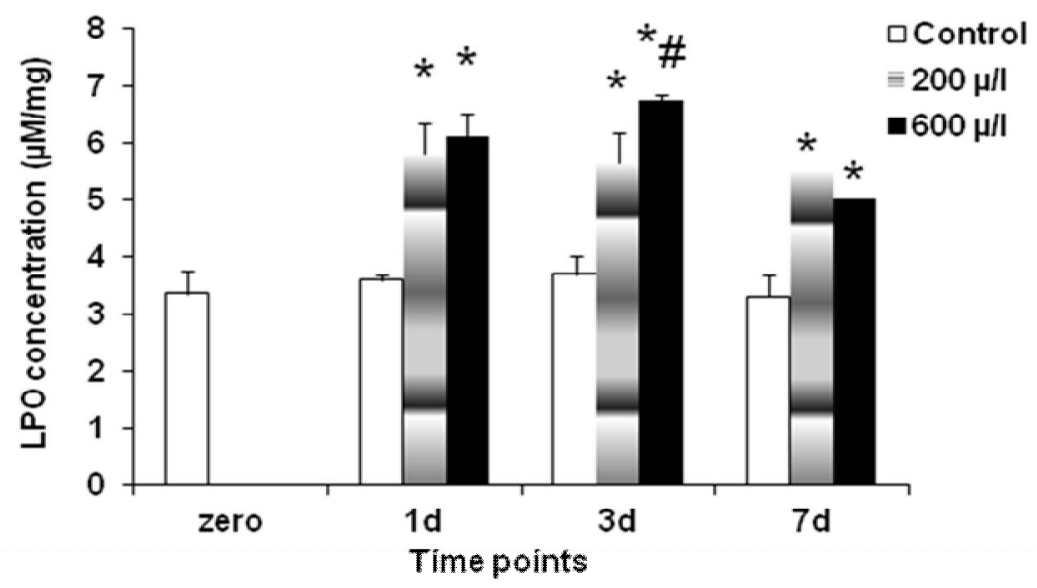

Fig. 1. Effect of the fertilizer (PMR) on adult L. carinatus lipid peroxidase activity for 7 days of exposure. * indicates a significant difference from the control and \# indicates a significant difference between treatments (ANOVA/KruskalWallis, $P \leq 0.05)$. 


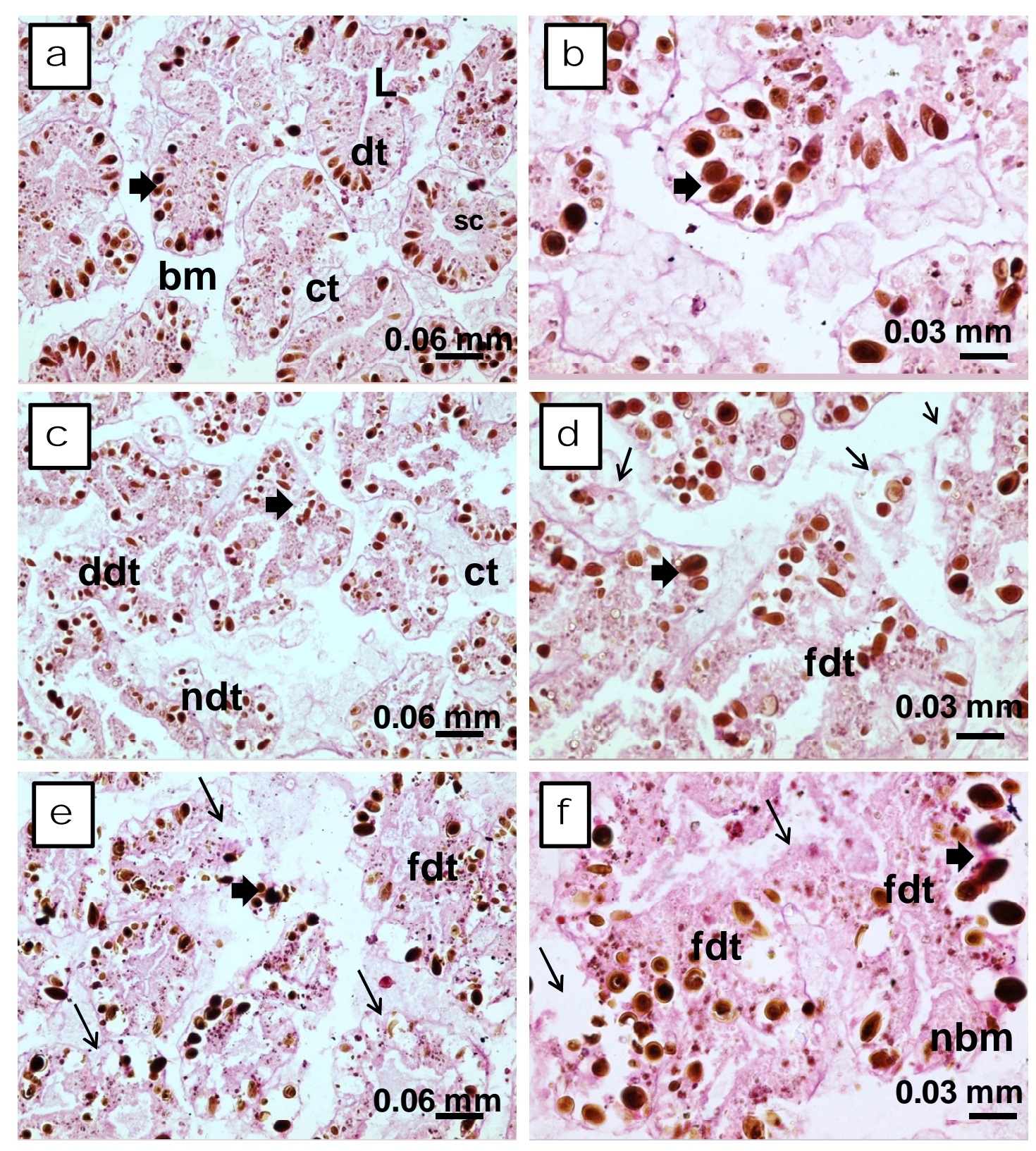

Fig. 2. Light micrographs of sections through digestive gland of adult L. carinatus stained with Haematoxylin and Eosin at $6 \mu \mathrm{m}$ thickness after 7 days of exposure to the fertilizer (PMR). a and b, control snails; c and d, $200 \mu \mathrm{l} / 1$ exposed snails; e and f, $600 \mu \mathrm{l} / 1$ exposed snails. dt; digestive tubule, L, lumen, bm; basement membrane, sc; secretory cell, ct; connective tissue, $\Rightarrow$; lipofuscin inclusions, ndt; necrotic digestive tubule, ddt; degenerated digestive tubule, fdt; fused digestive tubule, ${ }^{*}$; degeneration, nbm; necrotic basement membrane. 


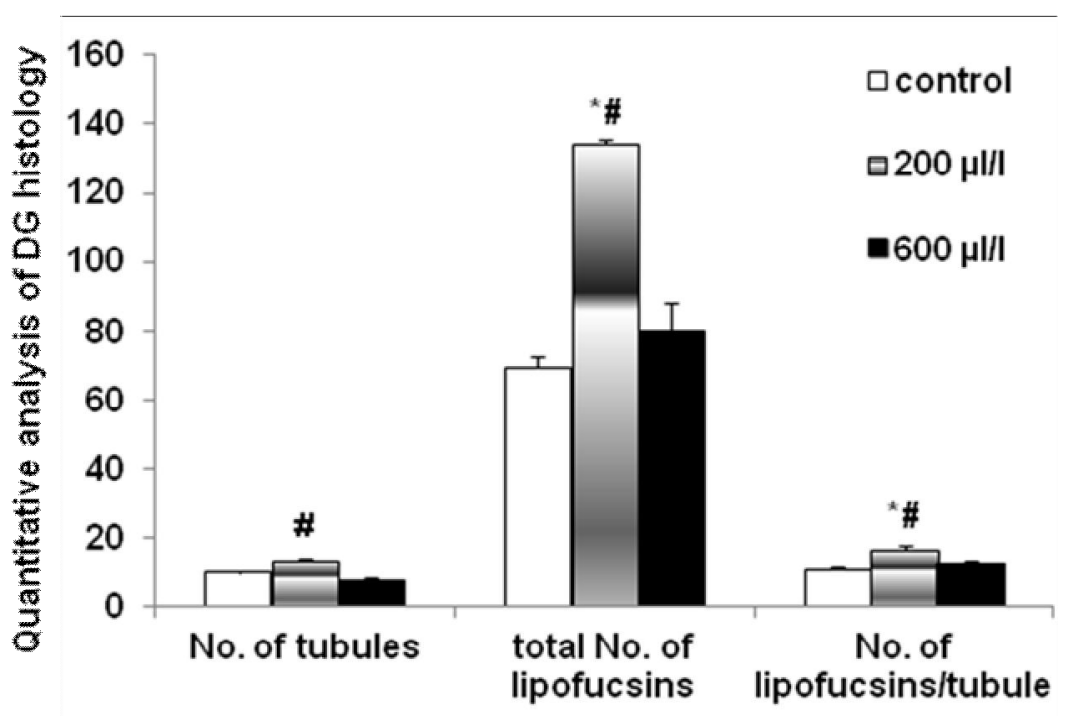

Analysis parameters

Fig. 3. Quantitative histological analysis of adult $L$. carinatus digestive gland after 7 days of exposure to the fertilizer (PMR). * indicates a significant difference from the control and \# indicates a significant difference between treatments (ANOVA/Kruskal-Wallis, $P \leq 0.05$ ).

\section{Discussion}

Caselio, the plant fertilizer caused different patterns of metal (essential and non-essential) accumulation in the exposed snails. Oxidative stress (peroxidation) was confirmed in the exposed snails digestive gland histological alterations and malondialdehyde (MDA) production. The findings of this investigation recorded the possible effect of PMR exposure to cause cell aging.

In the present investigation, several metals were picked and accumulated in the tissues of the snails from the experimental declorinated tap water with/without the effect of the fertilizer (PMR). Many studies on the tap water metals were done from different Governorates of Egypt. Drinking water samples from the Great Cairo, Egypt were 2.0, 0.15 and $2.78 \mu \mathrm{g} / \mathrm{l}$ for lead, cadmium and copper, respectively, a study done by Lasheen et al. (2008). They identified $\mathrm{pH}$ is a key factor for $\mathrm{Pb}$ release from pipes. $\mathrm{Fe}$, $\mathrm{Mg}, \mathrm{Pb}, \mathrm{Ni}, \mathrm{Cr}, \mathrm{Zn}, \mathrm{Cu}, \mathrm{Co}, \mathrm{Al}$, and $\mathrm{Cd}$ concentrations were analyzed in surface drinking water at Dakahlia Governorate, Egypt (Mandour and Azab, 2011). They mentioned that most of the analyzed metals ( $\mathrm{Al}, \mathrm{Cd}, \mathrm{Ni}$ and $\mathrm{Pb}$ ) exceeded the permissible limits. Heavy metals such as Cadmium, lead, chromium and iron were detected at Menoufia Governorate, Egypt in drinking tap water samples. The presence of those metals was correlated to alteration of the systemic physiology of the residents (Badr et al., 2011).

$\mathrm{Al}, \mathrm{Ti}, \mathrm{Pb}$ and $\mathrm{Cd}$ are representative toxic metals, which are biologically non-essential. However, $\mathrm{Cu}, \mathrm{Mg}$ and $\mathrm{Na}$ are essential elements for good biology of the cell, but their excess can cause oxidative stress then toxicity to the organism. In the present work, different accumulation patterns were taken place in the different analysed organs. The pattern for internalisation of different metals were different to each other. Some metals mainly accumulated in fatty tissue $(\mathrm{Cu}, \mathrm{Pb}, \mathrm{Na}$; digestive gland), muscular tissue $(\mathrm{Cu}, \mathrm{Pb}, \mathrm{Na}$; foot) or mineralized structures (Ti; shell, $\mathrm{Al}$, $\mathrm{Cd}$; operculum). As discussed by Tunca et al. (2013) who found correlations between metals accumulation and different tissues plus groups of metals in specific tissues in the freshwater crayfish, Astacus leptodactylus. In addition, accumulation of $\mathrm{Hg}$ was mainly in gills (Sheir et al., 2010) and Cd was in digestive gland (Sheir and Handy, 2010) of the marine mussel, Mytilus edulis exposed to $\mathrm{Hg}$ and $\mathrm{Cd}$, respectively. This could be explained that some metals accumulate through food and others through dissolved phase in water. Fisher et al. (1996) reported that dissolved phase of metals were predominantly bound to the shell, however, those ingested (food) predominantly associated with the soft parts. $\mathrm{Cd}, \mathrm{Cu}$ and $\mathrm{Pb}$ were analysed in different part of the gastropod Nerita lineata collected from different sites in soft tissues, shell and operculum, which showed different accumulation patterns for the essential and non-essential metals (Yap and Cheng, 2009). They added that soft tissues accumulate most for essential metals and least for non-essential metals. Pyatt et al. (1997) detected $\mathrm{Mn}$, Ti and $\mathrm{Cu}$ in tissues and shell of the freshwater snail Lymnaea stagnalis even they were not detectable in the collection site. Cairns et al. (1975) discussed the interactions between more than one stressor. They suggested that the effect may be synergistic, additive 
or antagonistic, and the combined stressors have less effect on the organism than the individual stressor does alone. As Al became more soluble and more bioavailable and toxic to aquatic biota at low/acidic pH (Muniz and Leivestad, 1980). Decreased essential metals and increased nonessential metals in tissues of the marine mussel, Mytilus edulis after pre-exposure history to mixture of pollutants was a sign of synergistic effect of the pollutants (Sheir et al., 2013).

In the present work, $\mathrm{Na}$ was not affected in tissues by the exposure to PMR. Beadle, (1969) discussed the possible role of the envelope and capsular membranes of the egg masses which separate the eggs from the external water are freely permeable to water and inorganic ions in Biompalaria sudanica and Lymnaea stagnalis embryos. Greenaway, (1970) discussed that $\mathrm{Na}$ concentration in the adult freshwater snail, Limnaea stagnalis followed the concentration of the external medium.

In the present investigation, LPO was increased significantly in the exposed snails than the control group. Increased lipid peroxidation (malonaldehyde) was a sign of exposure to a mixture of $\mathrm{Cu}$ and thiram (fungicide) in the gills and the digestive gland of the freshwater bivalve, Unio tumidus (Doyotte et al., 1997). Barata et al. (2005) recorded increase in lipid peroxidation and lipofuscin pigment in Daphnia magna juveniles after exposure to sublethal levels of menadione, paraquat, endosulfan, cadmium and copper for $48 \mathrm{~h}$. Sheehy, (1992) reported that peroxidation of the cell components can cause increase of lipofuscin pigments in the crayfish, Cherax quadricarinatus brain. In addition, Oxidative stress increase accumulation of lipofuscins as mentioned by Brunk and Terman (2002). In the present work, lipofuscin pigments were detected in the control and exposed snails digestive gland. Many studies were done on the lysosomal activity in the digestive glands of molluscs. Lipofuscin deposition was used as indicative of organic contaminant exposure revealing a general response to pollution in molluscs (Mytilus galloprovincialis, Marigomez and Baybay-Villacorta, 2003). The lysosomal system activity was limited altogether with raised lipofuscin inclusions and reduced amount of lipids in early winter of the mussel, $M$. galloprovincialis (Koukouzika et al., 2009). The presence of lipofuscins in the control digestive gland could be attributed to the unfavourable winter season that animals might be subjected to where they used their lipids contents as speculated by Koukouzika et al. (2009). Necrosis and degeneration of the digestive tubules were the major lesions of the exposed snails in the current study. Sharaf et al. (2015) recorded alteration in the histology and total lipids and protein of the digestive gland of the Land Snail after exposure to Methiocarb and Chlorpyrifos. Oxidative stress leads to lysosomal instability and causing apoptosis due to release of lysosomal contents into the cell, and might cause cell aging (crayfish, Sheehy, 1992; cell culture, Brunk and Terman, 2002). Koukouzika et al. (2009) suggested that digestive gland was the site of lipid storage. Marzabadi and Jones (1992) discussed the cause of lipofuscin pigments increase in metal exposed rat myocytes as (1) inhibition of lysosomal activity, (2) increased damage due peroxidative reactions, or (3) general toxicity with increased autophagy or transformation of lysosomal lipids to lipofuscin via lipid peroxidation (Dimitriadi et al., 2004). In the present study, the number of digestive tubules (20 $\mathrm{x}$ image) in the exposed snails to $200 \mu \mathrm{l} / 1$ was significantly higher than $600 \mu \mathrm{l} / 1$ exposed snails. That can be attributed to the fusion between the tubules which made it bigger in volume and lower in number. However, the number of the exposed snails to $200 \mu \mathrm{l} / 1$ was higher and in $600 \mu \mathrm{l} / 1$ exposed snails was lower than the control group. That could be due to the smaller tubules in the former, fused and large tubules in the later.

In conclusion, different investigated organs of $L$. carinatus accumulated metals from declorinated tap water of the experiment with/without the effect of Caselio, the plant fertilizer and depurated others. Therefore, $L$. carinatus is a good organism for detection of metals in drinking tap water. Caselio, (PMR) caused oxidative stress (lipid peroxidation) and increased induction of lipofuscins (aging-pigment) in the digestive gland of $L$. carinatus which is a biohazard for organisms health.

\section{Acknowledgment}

Author is grateful to Dr. John Bignell and Prof. Dr. Steve Feist, Histopathologists, Centre for Environment, Fisheries and Aquaculture Science, CEFAS, Weymouth, UK for their invaluable help in the identification of lipofuscin pigments in digestive gland sections.

\section{References}

Badr, E.A.E., Agrama, A.A.E., Badr, S.A.E. (2011). Heavy metals in drinking water and human health, Egypt. Nutr Food Sci, 41: 210-217.

Barata, C., Varo, I., Navarro, J.C., Arun, S., Porte, C. (2005).Antioxidant enzyme activities and lipid peroxidation in the freshwater cladoceran Daphnia magna exposed to redox cycling compounds. Comp Biochem Physiol C: Toxicol Pharmacol,140: 175-186.

Beadle, L.C. (1969). Salt and water regulation in the embryos of freshwater pulmonate molluscs. I. The embryonic environment of Biompalaria sudanica and Lymnaea stagnalis.J Exp Biol, 50: 473-479.

Brunk, U.T., Terman, A. (2002). Lipofuscin: mechanisms of age-related accumulation and influence on cell function. Free Rad Biol Med, 33: 611-619.

Buege, J.A., Aust, D.S. (1978). Microsomal lipid peroxidation. Meth Enzymol, 52: 302-310.

Cairns, Jr.J., Heath, A.G., Parker, B.C. (1975). The effects of temperature upon the toxicity of chemicals to aquatic organisms. Hydrobiologia, 47: 135-171.

Dimitriadi, V.K., Domouhtsidou, G.P., Cajaraville, M.P. (2004). Cytochemical and histochemical aspects of the digestive gland cells of the mussel Mytilus galloprovincialis (L.) in relation to function. J Molec Histol, 35: 501-509. 
Dodd, J.R. (1965). Environmental control of strontium and magnesium in Mytilus. Geochimica et Cosmochimica Acta, 29: 3853-98.

Doyotte, A., Cossu, C., Jacquin,M_C., Babut, M., Vasseur, P. (1997). Antioxidant enzymes, glutathione and lipid peroxidation as relevant biomarkers of experimental or field exposure in the gills and the digestive gland of the freshwater bivalve Unio tumidus. Aquat Tocxicol, 39: 93110.

Driscoll, C.T., Postek, K.M. (1996). The chemistry of aluminum in surface waters. In: Sposito, G., (ed). The Environmental Chemistry of Aluminum , 2nd ed., New York, Lewis Publishers, 363-418.

El-Gendy, K.S., Radwan, M.A., Gad, A.F. (2011). Feeding and Growth Responses of the Snail, Theba pisana to Dietary Metal Exposure. Arch Environ Contam Toxicol, 60: 272-280.

Emsley, J. (2001). Titanium. In: Nature's Building Blocks: an A-Z guide to the elements. Oxford University Press, Oxford, 452.

Federici, G., Shaw, B.J., Handy, R.D. (2007). Toxicity of titanium dioxide nanoparticles to rainbow trout (Oncorhynchus mykiss): Gill injury, oxidative stress, and other physiological effects. Aquat Toxicol, 84: 415-430.

Fisher, N.S., Teyssié, J.-L., Fowler, S.W., Wang, W.-X. (1996). Accumulation and retention of metals in mussels from food and water: a comparison under field and laboratory conditions. Environ Sci Technol, 30: 32323242.

Greenaway, P. (1970). Sodium regulation in the freshwater mollusc Limnaea stagnalis (L.) (Gastropoda: Pulmonata). J Exp Biol. 53: 147-163.

Gupta, P.K., Khangarot, B.S., Durve, V.S. (1981). The temperature dependence of the acute toxicity of copper to a freshwater pond snail, Viviparus bengalensis L. Hydrobiologia. 83: 461-464.

Havas, M. (1985). Aluminum bioaccumulation and toxicity to Daphnia magna in soft water at low $\mathrm{pH}$. Can J Fish Aquat Sci, 42:1741-1748.

Hu, M-Y., Ye,Y-F., Xue, L-Y., Tang, Z-Y. (2015). Tissue-Specific Metabolic Responses of Cyprinus flammans to Copper. Arch Environ Contam Toxicol, 69: $112-122$.

Huang, H., Wu, J.Y., Wu, J.H. (2007). Heavy Metal Monitoring Using Bivalved Shellfish from Zhejiang Coastal Waters, East China Sea. Environ Monitor Assess, 129: 315-320.

Ibrahim, N., Mat, I. (1995). Trace element content in relation to the body weight of the marine bivalve, Anadara granosa with special reference to the application of INAA and ICP-AES as analytical techniques. J Radioanalyt Nuc Chem, 195: 203-208.

Kar, I., Mukhopadhayay, S.K., Patra, A.K., Pradhan, S. (2015). Metal Concentrations and Histopathological Changes in Goats (Capra hircus ) Reared Near an Industrial Area of West Bengal, India. Arch Environ Contam Toxicol, 69: 32-43.

Kesavan, K., Murugan, A., Venkatesan, V., Kumar. V. (2013). Heavy Metal Accumulation in Molluscs and sediment from Uppanar Estuary, Southeast Coast of India. Thalassas, 29: 15-21.

Koukouzika, N., Raftopoulou, E.K., Dimitriadis, V.K. (2009). Seasonal differences of lysosomal, lipid and lipofuscin parameters in the digestive gland of the mussel Mytilus galloprovincialis. J Mollus Stud, 75: 261-267.

Lance, E., Josso, C., Dietrich, D., Ernst, B., Paty, C., Senger, F., Bormans, M., Gerard, C. (2010). Histopathology and microcystin distribution in Lymnaea stagnalis (Gastropoda) following toxic cyanobacterial or dissolved microcystin-LR exposure. Aquat Toxicol, 98: 211-220.

Lasheen, M.R., El-Kholy, G., Sharaby, C.M., Elsherif, I.Y., El-Wakeel, S.T. (2008). Assessment of selected heavy metals in some water treatment plants and household tap water in Greater Cairo, Egypt. Manag Environ Qual, 19: 367-376.

Leslie, A.R. (1994). Handbook of Integrated Pest Management for Turf and Ornamentals. 1st Edition. 661.

Nair, V., Turner, G.E. (1984). The thiobarbituric acid test for lipid peroxidation structure of the adduct with malondialdehyde. Lipids, 19: 84-95.

Mandour, R.A., Azab, Y.A. (2011). The Prospective Toxic Effects of Some Heavy Metals Overload in Surface Drinking Water of Dakahlia Governorate, Egypt. Internat J occupat environ Med, 2: 245-253.

Marigomez, I., Baybay-Villacorta, L. (2003). Pollutant specific and general lysosomal responses in digestive cells of mussels exposed to model organic chemicals. Aquat Toxicol, 64: 235-257.

Martin, D.J., Rainbow, P.S. (1998). The kinetics of zinc and cadmium in the haemolymph of the shore crab Carcinus maenas (L.). Aquat Toxicol, 40: 203-231.

Marzabadi, M.R., Jones, C.B. (1992). Heavy metals and lipofuscinogenesis. A study on myocardial cells cultured under varying oxidative stress. Mechanis Age Develop, 66: 159-171.

Mohamadein, A., Desouky, M.M. (2002). Effect of cadmium as a water pollution on the filtration rate and the histology of the siphon of the marine clam Venerupisa urea. Eypt J Aquat Biol Fish, 6:125-139.

Muniz, I.P., Leivestad, H. (1980). Acidification effects on freshwater fish. In: Ecological Impact of Acid Precipitation, 84-92.

Osredkar, J., Sustar, N. (2011). Copper and Zinc, Biological Role and Significance of Copper/Zinc Imbalance. J Clin Toxicol, S3: 001.

Peakall, D.B. (1994). The role of biomarkers in environmental assessment (1). Introduction. Ecotoxicology, 3: 157-160.

Pyatt, F.B., Pyatt, A.J., Pentreath, V.W. (1997). Distribution of metals and accumulation of lead by different tissues in the freshwater snail Lymnaea stagnalis (L.). Environ Toxicol Chem, 16: 1393-1395.

Rainbow, P.S., Black, W.H. (2005). Physicochemistry or physiology: cadmium uptake and effects of salinity and osmolality in three crabs of different ecologies. Mar Ecolo Prog Ser, 286: 217-229. 
Rainbow, P.S., White, S.L. (1985). On the metabolic requirement for copper and zinc in molluscs and crustaceans. Mar Environ Res, 16: 215-299.

Rockwood, J.P., Jones, D.S., Coler, R.A. (1990). The effect of aluminum in soft water at low $\mathrm{pH}$ on oxygen consumption by the dragonfly Libellula julia Uhler. Hydrobiologia, 190: 55-59.

Romeis, B. (1989). Mikroskopische Technik. Auflage, Urban and Schwarzenberg, Munchen- WienBaltimore, 17: 235-236.

Romani, A.M.P. (2013). Magnesium in Health and Disease". In: Sigel A., Sigel H., Sigel R.K.O. (eds). Interrelations between Essential Metal Ions and Human Diseases. Chapter 3. Metal Ions in Life Sciences. Springer, 49-79.

Sharaf, H.M., Salama, M.A., Abd El-Atti, M.S. (2015). Biochemical and Histological Alterations in the Digestive Gland of the Land Snail Helicella vestalis (Locard, 1882) Exposed to Methiocarb and Chlorpyrifos in the Laboratory. Internat J Sci Res, 4: 334-343.

Sheir, S.K. (2015). Impacts of short-term exposure of Caselio (plant fertilizer) on The freshwater snail, Lanistes carinatus (Ampullariidae, Mollusca). Res J Pharmacet Biol Chem Sci, 6: in press.

Sheir, S.K., Handy, R.D. (2010). Tissue injury and cellular immune responses to cadmium chloride exposure in the common mussel Mytilus edulis: modulation by lipopolysaccharide. Arch Environ Contam Toxicol, 59: 602-613.

Sheir, S.K., Handy, R.D., Galloway, T.S. (2010). Tissue injury and cellular immune responses to mercuric chloride exposure in the common mussel Mytilus edulis: modulation by lipopolysaccharide. Ecotoxicol Environ Saf, 73: 1338-1344.

Sheir, S.K., Handy, R.D., Henry, T.B. (2013). Effect of pollution history on immunological responses and organ histology in the marine mussel Mytilus edulis exposed to cadmium. Arch Environ Contam Toxicol, 64: 701-716.

Sheehy, M.R.J. (1992). Lipofuscin age-pigment accumulation in the brains of ageing field- and laboratory reared crayfish Cherax quadricarinatus (von Martens) (Decapoda: Parastacidae). J Exp Mar Biol Ecol, 161: 7989.

Siwela, A.H. Nyathi, C.B., Naik, Y.S. (2010). A comparison of metal levels and antioxidant enzymes in freshwater snails, Lymnaea natalensis, exposed to sediment and water collected from Wright Dam and Lower Mguza Dam, Bulawayo, Zimbabwe. Ecotoxicol Environ Saf, 73: 1728-1732.

Tilman, D., Fargione, J., Wolff, B., D'Antonio, C., Dobson, A., Howarth, R., Schindler, D., Schlesinger, W.H., Simberloff, D., Swackhamer, D. (2001). Forecasting Agriculturally Driven Global Environmental Change. Science, 292: 281-284.

Tunca, E., Ucuncu, E., Ozkan, A.D., Ulger,Z.E., Tekinay, T. (2013). Tissue distribution and correlation profiles of heavy-metal accumulation in the freshwater crayfish Astacus leptodactylus. Arch Environ Contam Toxicol. 64:676-691.

Weibel, E.R., Kistler, G.S., Scherle W.F. (1966). Practical stereological methods for morphometric cytology. J Cell Biol, 30: 23-38.

Werner, W. (2009). Fertilizers, 6. Environmental Aspects. In: Ullmann's Encyclopedia of Industrial Chemistry, Wiley-VCH, Weinheim.

Yap, C.K., Cheng, W.H. (2009). Heavy metal concentrations in Nerita lineata: the potential as a biomonitor for heavy metal bioavailability and contamination in the tropical intertidal area. Mar Biodiver Rec, 2: e46. 